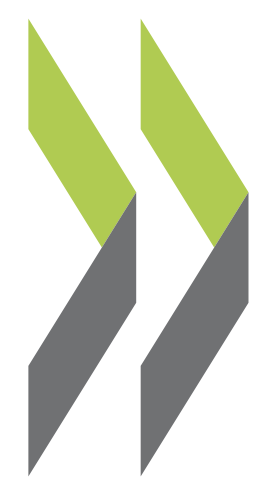

OECD Social, Employment and Migration Working Papers No. 30

Labour Protection in China: Challenges Facing Labour Offices and Social Insurance

\title{
Anders Reutersward
}

https://dx.doi.org/10.1787/325131488300 
Labour Protection in China: Challenges Facing

Labour Offices and Social Insurance

Anders Reutersward

\section{0}


Organisation de Coopération et de Développement Economiques

Organisation for Economic Co-operation and Development

07-Nov-2005

DIRECTORATE FOR EMPLOYMENT, LABOUR AND SOCIAL AFFAIRS

English text only

EMPLOYMENT, LABOUR AND SOCIAL AFFAIRS COMMITTEE

OECD SOCIAL, EMPLOYMENT AND MIGRATION WORKING PAPERS No. 30

LABOUR PROTECTION IN CHINA: CHALLENGES FACING LABOUR OFFICES AND SOCIAL INSURANCE

Anders Reutersward

JEL Classification: J2, J42, J52, J6, J8. 


\title{
OECD SOCIAL, EMPLOYMENT AND MIGRATION WORKING PAPERS
}

\author{
http://ww.oecd.org/els/workingpapers
}

This series is designed to make available to a wider readership selected labour market, social policy and migration studies prepared for use within the OECD. Authorship is usually collective, but principal writers are named. The papers are generally available only in their original language - English or French - with a summary in the other.

Comment on the series is welcome, and should be sent to the Directorate for Employment, Labour and Social Affairs, 2, rue André-Pascal, 75775 PARIS CEDEX 16, France.

The opinions expressed and arguments employed here are the responsibility of the author(s) and do not necessarily reflect those of the OECD

\section{Applications for permission to reproduce or translate all or part of this material should be made to:}

\author{
Head of Publications Service \\ OECD \\ 2, rue André-Pascal \\ 75775 Paris, CEDEX 16 \\ France
}

Copyright OECD 2005 
DELSA/ELSA/WD/SEM(2005)9

\section{EXECUTIVE SUMMARY}

One of the key institutional outcomes of China's economic reforms has been to create a new role for employers that is separate from the state, and allows enterprises to concentrate on their business. To protect workers, the government has set up public institutions for many social and administrative functions that until recently pertained to work units (danwei), or did not exist. This paper focuses on three such functions for which the 1994 Labour Law makes the government responsible: employment services, labour inspection and social insurance.

OECD experience of specific policy solutions has potential interest for China on several points: for example in the administration of social insurance funds or in ensuring adequate co-ordination between "passive" income support and "active" job-search assistance for the unemployed. A more fundamental problem, however, is that all formal labour market institutions in China - as in other developing countries - have limited application outside the most developed part of the economy, which consists mainly of urban formal enterprises. Implementing labour law and social insurance is generally difficult in the less productive rural and informal segments of the labour market. But real incomes are rising in most parts of the economy, and the present scale of rural-urban migration and economic interdependence makes it urgent to reduce institutional inequity as far as possible.

Administrative controls on migration have for a long time exacerbated the division between urban and rural labour markets. This division persists, but it has become less rigid, as the household registration system (hukou) has been partly liberalised, and restrictions on the recruitment of migrants have been abolished. Social insurance is gradually extended to rural migrants and workers in "flexible" forms of employment. These developments enhance both efficiency and social equity, but they need to be consolidated and followed up by further reforms in the same direction.

The public functions studied here fall under the Ministry of Labour and Social Security at national level, and under Labour Bureaus at lower levels. This structure appears to permit the co-ordination that is needed to achieve a coherent focus on selected priority goals, such as the promotion of formal employment contracts and enrolment in social insurance. Specialised office networks have been developed in urban areas, but much less so in rural areas. Insofar as the traditional client groups in the urban formal economy are concerned, the office networks appear relatively well equipped by international standards. Clearly, however, any future policy to extend formal employment institutions to rural areas would require major further expansions of administrative resources.

Concerning employment services, both OECD and Chinese experience suggests that the counselling and monitoring of unemployed job seekers who receive public support (unemployment benefits or special support of the laid-off) must have high priority. As more and more workers adhere to unemployment insurance, the numbers of registered benefit claimants will also increase and this will put pressure on the administration. But in addition, labour bureaus have an important role to play as intermediaries between rural migrants and urban employers. Recruitment efforts that target migrants are often large in scale, and so give limited room for paying attention to each individual. However some individual services should, as a rule, be afforded to those who demand it when resources permit. It is no longer appropriate to discriminate between clients according to their hukou status. 
The labour inspectorate cannot monitor all enterprises, but it frequently takes action in response to individual complaints. By making this service relatively accessible and effective, the inspectorate has become a safety valve that may be particularly important in China, where other possible channels for workers' complaints, such as trade unions, are not independent of political powers or enterprise management. A further concern of special importance in China is that the country needs to remove grounds for suspicion that it tolerates poor labour standards in order to attract foreign investment. This appears to require more inspections of working time and wage payments. Foreign actors and non-governmental organisations (NGO) can play a complementary role in putting pressure on some enterprises, but they cannot replace an effective labour inspectorate.

The governance of social insurance involves many decentralised decisions about contribution rates and benefit levels. In contrast to most OECD countries, which standardise these decisions at national level, China's size and diversity impose flexibility. The national government encourages provincial governments to harmonise the system and to centralise the pooling of social insurance funds in each province. But contribution rates are often reduced for certain groups, especially rural migrants and workers in small private firms, who may also be offered a choice between alternative insurance packages. While such differentiation is justified, it may not be sufficient to attract rural migrants unless the accumulated entitlements are portable. The social insurance system as a whole needs to be revised with a view to actual mobility patterns in the labour market. The pension programme, in particular, is unsuitable for migrants because it requires ten contribution years in the same locality. This limit should be abolished, and the administration should be equipped to take account of all contributions made by an individual during his or her lifetime, regardless of where they were paid. A more centralised administration might facilitate this, but with good co-ordination it should also be possible in a decentralised system. 


\section{RÉSUMÉ}

Un des résultats institutionnels clés des réformes économiques en Chine a été la promotion du nouveau rôle joué par les employeurs, en dehors de l'Etat, qui permet aux entreprises de gérer leurs propres affaires. Le gouvernement, pour protéger les travailleurs, a créé des institutions publiques couvrant de nombreuses fonctions sociales et administratives qui, jusqu'à une date récente, ne concernaient que les unités de travail (danwei) ou n'existaient pas. Ce document se concentre sur trois des fonctions que la Loi de 1994 sur le travail place sous la responsabilité du gouvernement : les services de l'emploi, l'inspection du travail et l'assurance sociale.

L'expérience de l'OCDE en matière de solutions politiques spécifiques présente un intérêt potentiel pour la Chine à plusieurs points de vue : par exemple dans l'administration des fonds d'assurance sociale ou en assurant de manière adéquate la coordination entre les politiques passives d'indemnité et les politiques actives d'assistance destinées aux chômeurs à la recherche d'un emploi. Un problème plus fondamental existe cependant, c'est que pour toutes les réglementations du marché du travail formel en Chine, comme dans les autres pays en voie de développement, l'application reste limitée aux secteurs les plus développés de l'économie, principalement aux entreprises formelles urbaines. Il est difficile d'appliquer les lois relatives au travail et à l'assurance sociale dans les secteurs ruraux les moins productifs et dans les segments informels du marché du travail. Mais les revenus réels s'accroissent dans la plupart des secteurs de l'économie, alors que le dynamisme actuel de la migration rurale/urbaine et l'interdépendance économique rendent urgente une réduction aussi rapide que possible des inégalités institutionnelles.

Les contrôles administratifs des migrations internes ont soutenu pendant longtemps la séparation entre les marchés du travail rural et urbain. Cette division persiste, même si elle est devenue moins rigide, avec un système d'enregistrement des ménages (hukou) en partie libéralisé, et la suppression des restrictions au recrutement des migrants. L'accès à l'assurance sociale sera progressivement étendu aux migrants qui viennent des zones rurales et aux personnes ayant des emplois «flexibles ». Ces développements améliorent l'efficacité et l'équité sociale, mais ils nécessitent d'être consolidés et poursuivis plus avant dans la même direction.

Les fonctions publiques étudiées ici sont sous la responsabilité du Ministère du Travail et de la Sécurité sociale au niveau national, et sous celle des bureaux pour l'emploi à un niveau moins élevé. Ce type de structure semble permettre la coordination nécessaire à une orientation cohérente vers des buts bien précis, telles la promotion de contrats de travail officiels et l'adhésion à l'assurance sociale. Des réseaux administratifs ont été développés dans les secteurs urbains et, à un moindre niveau, dans les zones rurales. En ce qui concerne les groupes de clients traditionnels de l'économie urbaine formelle, le réseau des bureaux pour l'emploi peut apparaître relativement bien équipé par comparaison internationale. Cependant, toute politique visant à étendre les institutions formelles pour l'emploi aux zones rurales nécessitera aussi un accroissement des ressources administratives.

En ce qui concerne les services de l'emploi, les expériences des pays de l'OCDE et de la Chine démontrent que les activités de conseil et le suivi des demandeurs d'emploi au chômage qui perçoivent des aides publiques (allocations de chômage ou indemnités spéciales de licenciement) doivent être hautement 
prioritaires. Comme de plus en plus de travailleurs adhèrent à l'assurance chômage, le nombre de ceux qui réclament leurs droits va aussi en augmentant, et cela entraînera des pressions sur l'administration. En outre, les bureaux pour l'emploi ont un rôle important à jouer en tant qu'intermédiaires entre les migrants ruraux et les employeurs urbains. Les efforts de recrutement visant les migrants concernent souvent un grand nombre de personnes et ne permettent guère qu'on accorde beaucoup d'attention aux cas individuels. Toutefois, certains services individuels devraient devenir la règle et être accordés, quand les ressources le permettent, à ceux qui en font la demande. Il n'est plus d'actualité de continuer à faire la distinction entre les clients selon leurs statuts (hukou) respectifs.

L'inspection du travail ne peut pas surveiller toutes les entreprises, mais elle agit fréquemment en réponse à des plaintes individuelles. En rendant ce service relativement accessible et efficace, l'inspection est devenue une soupape de sécurité qui peut être particulièrement importante en Chine, où les autres canaux possibles par lesquels les ouvriers peuvent exprimer leurs problèmes tels que les syndicats, ne sont pas indépendants du pouvoir politique ni du management des entreprises. En plus, un défi d'importance particulière pour la Chine sera de supprimer les motifs potentiels de soupçon qu'on tolère de mauvaises conditions de travail en vue d'attirer les investissements étrangers. Cela exigera sans doute des inspections plus fréquentes, visant notamment le temps de travail et le règlement des salaires. Les partenaires étrangers et les organisations non gouvernementales (ONG) peuvent jouer un rôle complémentaire en exerçant des pressions sur certaines entreprises, mais ils ne peuvent pas remplacer une inspection efficace du travail.

La gouvernance de l'assurance sociale implique la décentralisation de nombreuses décisions relatives aux taux de cotisation et niveaux de bénéfices. Contrairement à la plupart des pays de l'OCDE, où les décisions de ce genre sont centralisées au niveau national, la taille de la Chine et sa diversité imposent plus de souplesse. Le gouvernement national encourage les gouvernements provinciaux à harmoniser le système et à centraliser les fonds communs d'assurance sociale dans chaque province. Mais les taux de cotisation sont souvent réduits pour certains groupes, particulièrement les migrants ruraux et les ouvriers des petites sociétés privées, qui peuvent également se voir proposer un choix divers d'assurances complémentaires. Bien qu'une telle différentiation soit justifiée, elle ne suffira pour attirer les migrants ruraux que si leurs droits accumulés de pensions sont transportables. Le système d'assurance sociale dans son ensemble mérite d'être révisé en fonction des coutumes de mobilité qui prévalent actuellement sur le marché du travail. Le programme de pension, en particulier, est mal adapté aux migrants car il requiert dix ans de cotisation dans la même localité. Cette contrainte devrait être supprimée, et l'administration doit se donner les moyens de tenir compte de toutes les contributions apportées par un individu tout au long de sa vie, indépendamment du lieu de leur paiement. Une administration plus centralisée pourrait faciliter cette tâche, mais avec une bonne coordination cela serait aussi possible au sein d'un système décentralisé. 
TABLE OF CONTENTS

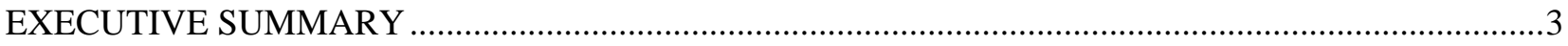

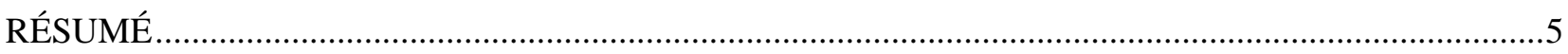

LABOUR PROTECTION IN CHINA: CHALLENGES FACING LABOUR OFFICES AND SOCIAL

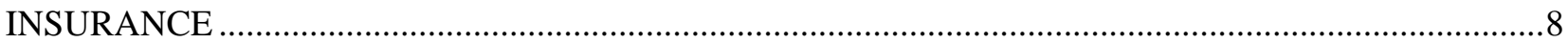

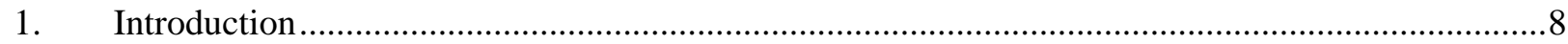

2. Extending the reach of formal employment institutions ...............................................................9

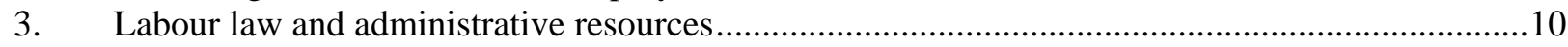

4. Employment services and related programmes...........................................................................16

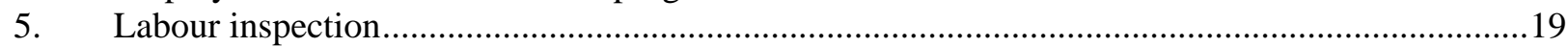

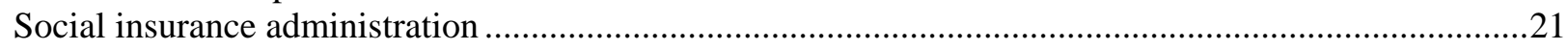

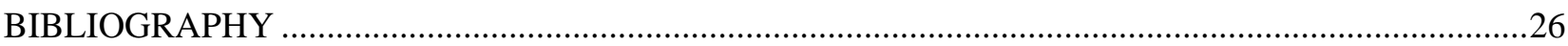




\section{LABOUR PROTECTION IN CHINA: CHALLENGES FACING LABOUR OFFICES AND SOCIAL INSURANCE ${ }^{1}$}

\section{Introduction}

1. China's economic reforms have established a new relationship between enterprises, workers and the State, placing the public administration at arm's length from most economic decisions in the market. The Enterprise Law and the Labour Law, both dating from 1994, assign employers a new role, which is separate from government, and permits enterprises to concentrate on their business activities. Many administrative and social responsibilities have therefore been removed from what until recently was called work units (danwei), while the State is facing the need to develop a variety of institutions that previously did not exist or had different functions. This process is well under way but much remains to be done. The problems encountered are still partly related to China's peculiar heritage, but the principal goals and policy constraints are comparable to those found in many developing market economies.

2. This paper focuses on public institutions for employment services, labour inspection and social insurance. A starting point is provided by Chapter 16 in China in the World Economy: The Domestic Policy Challenges (OECD, 2002), which reviewed the principal issues of labour market and social policy. Several of its recommendations concerned the need to overcome labour market segmentation, especially between urban and rural workers, and between formal and informal employment, and to extend social insurance to a bigger part of the workforce. Analysis of labour mobility suggested that the urban formal economy was still marked by low mobility by OECD standards, notwithstanding many lay-offs, while, by contrast, many informal jobs were too unstable to generate much on-the-job learning or adequate income.

3. Some governance issues of relevance mainly in China's urban areas are comparable to those in developed OECD countries, making it pertinent to draw on their experience. These concern, for example, the relationship between unemployment insurance (UI) administration and "active" measures to promote job search, and, in social insurance, questions about fund management and how these are linked with other policy decisions. These questions are briefly considered under the respective headings below. But the principal governance problem to which this paper is devoted is that formal employment institutions in general are difficult to apply outside the most developed parts of China's labour market. The next section considers the scope for policies to promote a gradually wider use of relevant institutions. This is followed by a discussion of legislation, administrative resources and recent efforts to bridge the urban-rural divide. The last three sections look in turn at each of the selected functions of public administration.

1. This Working Paper is a revised version of Chapter 11 of the OECD publication Governance in China (OECD, 2005a). It reports findings of an OECD (DELSA/ELSAC) mission to Beijing, Sichuan and Fujian in March 2004, organised with the support of China's Ministry of Labour and Social Security. Mrs. Sylvie Mouranche, French Ministry of Employment, Social Cohesion and Housing and Ms Hiroko Uchimura, Institute of Developing Economies, Chiba, Japan, contributed to the sections on, respectively, labour inspection and pensions. 


\section{Extending the reach of formal employment institutions}

4. Protecting workers' rights is intrinsically difficult in a situation of labour surplus. With rural under-employment estimated at 150 million persons or more, and net rural-urban migration flows amounting to perhaps 10 million persons per year, China's labour market will remain for the foreseeable future a "buyer's market" where most job seekers have a weak bargaining position. This is bound to influence wages and other negotiable employment conditions, and it limits the scope of what can realistically be achieved by means of legal regulation of the labour market. Even so, workers have a legitimate claim on basic labour standards, an orderly and predictable application of the law, and adherence to contractual agreements.

5. A key challenge of public governance is therefore to develop institutions that can pursue such objectives under the varying conditions that prevail in different parts of the economy. Existing labour market institutions, as reformed over the past few decades, are largely similar to those of more developed economies, but their impact - in China, as in many low and middle-income countries - remains highly concentrated in a "formal" segment of the urban job market. Judging from the coverage of pension insurance, for example, this market segment can be considered to include around 150 million workers or one-fifth of total employment (two-fifths of non-agricultural employment). It primarily concerns employees in public institutions and large and medium-sized urban enterprises, along with some of the workers in small firms known to urban business registers, but few rural workers. Table 1 shows the relative size of the main labour market segments. ${ }^{2}$ As discussed further below (Table 2), efforts to extend the social insurance coverage have until now mostly targeted urban workers, but rural migrants and some other groups have attracted increasing policy attention. Similar limitations apply, albeit with many variations, to the enforcement of most provisions in labour legislation.

6. To some extent it is inevitable that the spread of formal employment institutions across the labour market will follow, rather than precede, the development of the economy. Nevertheless, the present scale of rural-urban migration and economic interdependence makes it important to reduce institutional inequity as far as possible. This will require a sustained effort over many years, which should aim to achieve a gradually more equal treatment of the principal groups of employees, especially with respect to the use of formal labour contracts and participation in social insurance.

7. OECD experience suggests that governments in general have good reason to promote a "formalisation" of informal jobs (see Chapter 5, Employment Outlook, OECD, 2004). This requires an effective enforcement of labour law, social insurance and taxation of wage income and profits, and it may also motivate measures to limit red tape, and to reduce taxes and social contributions, so that the cost of formal employment does not become too high relative to the potential benefits for workers and employers. For society as a whole, such policies can enhance both efficiency and equity because informality tends to be associated with several undesirable job conditions. The short duration and casual nature of many informal jobs makes them unlikely to motivate sufficient investment in job-specific human capital. In addition, employers who hire workers informally are often informal themselves, a situation known to limit their access to legitimate business contacts, formal credits and legal protection, e.g. against fraud and

2. The overall employment distribution across different parts of the labour market can be estimated only approximately because it requires a combination of data from different sources (Chapter 16 in OECD, 2002). Table 1 uses official estimates of total employment and the agricultural share, based on surveys of population changes, and more detailed data from separate official sources for urban and rural areas. 
corruption. All these factors tend to reduce the chances of business expansion and productivity growth in informal firms. ${ }^{3}$

8. To promote the above-mentioned objectives in the near future and in a longer-term perspective, a three-pronged approach appears justified with the following elements:

1. Develop administrative capacity and front-line offices for employment services, labour inspection and social insurance so that they can cover gradually larger parts of the urban and rural labour force.

2. Promote the use of formal employment contracts and extend social insurance to additional groups in the labour market. Priority groups in the near future should include workers in small firms, rural migrants in urban areas and selected groups in rural areas.

3. Inform all workers about their rights and insist that the minimum wage, working time and safety rules apply even in the absence of formal contracts.

\section{Labour law and administrative resources}

9. The 1994 Labour Law aims to "protect the legitimate rights and interests of labourers, readjust labour relationship, establish and safeguard a labour system suited to the socialist market economy, and promote economic development and social progress" (Chapter 1 of the law). Sections 2 and 3 specify that the law as a whole applies to all employers ("enterprises and individual economic organisations") and their employees, and that workers have "the right to be employed on an equal basis."

10. The rules about individual labour contracts resemble those in OECD countries on essential points (Chapter 3 of the law). Contracts must be established in writing and follow "the principles of equality, voluntariness and unanimity through consultation". They can be fixed-term or flexible (indefinite), but after ten years with the same employer the worker has a right to a flexible contract. An employer who terminates a contract must give 30 days' notice and pay severance benefits according to separate regulations. Children under 16 must not be employed. Normal working time is up to 8 hours per day and 44 hours per week, while overtime is possible at higher pay within the limits of 3 hours per day and 36 hours per month (Chapter 4 of the law).

11. The rules about collective bargaining also resemble those in OECD countries to some extent, but here there is a bigger difference in practice due to the official nature of China's trade unions. The Labour Law does not regulate the establishment of trade unions, an area where the key role pertains to the AllChina Federation of Trade Unions - a "mass organisation" with close relations to the political leadership. Where trade unions exist, the Labour Law, Section 33, gives them an exclusive right to conclude collective agreements. As an exception, elected representatives of staff and workers can conclude collective agreements with an enterprise "where the trade union has not yet been set up". Once concluded, a collective agreement must be registered with the local government.

3. Such negative effects of informality in OECD economies, reviewed in the 2004 Employment Outlook, were observed, for example, in central and eastern Europe (Belev, 2003), various EU countries (Avignon Academy, 2002) and Mexico (Winkler, 1997). Informality has also been found to contribute to low productivity growth and uneven economic development in Brazil and other Latin American countries (Gonzaga, 2004 and McKinsey\&Company, 2004, quoted in OECD Economic Surveys: Brazil, 2005b). 
12. The state's responsibilities according to the Labour Law fall upon the labour bureaus of central, regional and local governments down to the county level. These responsibilities mainly concern the following:

1. Promotion of employment. Chapter 2 expresses a general policy commitment towards employment and economic and social development, and it calls for the provision of employment services. Local governments' labour bureaus mostly organise these services themselves, but they also promote and standardise job agencies run by other bodies.

2. Regulatory powers. Local governments give detailed rules about working time and holidays (Chapter 4) and set minimum wages (Chapter 5), following national and provincial norms. Governments at various levels issue rules about the employment of youth aged 16-18 and women (Chapter 7). They also regulate vocational training, which they may sponsor "where conditions permit” although employers carry the main responsibility (Chapter 8).

3. Social insurance (Chapter 9). Workers have a right to public social insurance covering retirement, illness, occupational injury and disease, unemployment and maternity. Labour bureaus must set up agencies to administer these programmes and their funds.

4. Arbitration committees (Chapter 10), appointed to resolve labour disputes, gather representatives of workers, employers and the labour bureaus. The latter are also responsible for supervision and administration.

5. The labour inspectorate (Chapter 11) has a wide remit to check that employers follow the law, along with powers to stop unlawful practices. ${ }^{4}$ However, this does not concern the inspection of occupational health and safety which, according to recent legislation, falls under the Ministry of Health, although the Labour Law's Chapter 6 contains general rules. ${ }^{5}$

\section{Administrative networks}

13. The policies considered here fall under the Ministry of Labour and Social Security (MOLSS) at national level and under Bureaus of Labour and Social Insurance (commonly called Labour Bureaus) at province and city/county levels. Social insurance is generally managed in separate departments within the labour bureaus, called social insurance agencies, which enjoy a degree of independence and have their own budgets. Other departments cover employment services, training and labour inspection (also called employment security supervision). The respective office networks are largely new and well developed in urban areas, but much less so in rural areas.

14. Further rapid development is expected, with gradually better coverage of the territory, more specialised offices and more qualified staff for the different functions. Organisational structures vary, but as a rule the government of any territorial unit encompasses most areas of public policy; if there is no specialised office, the public may ask for the corresponding services in a multi-purpose office. Many localities, including four prefecture-level cities visited by an OECD team in March 2004, have specialised job centres and social insurance outlets at the city and/or district levels, while the existing offices at lower administrative levels are less specialised (in urban areas, street communities and neighbourhood communities, see Box 1). The street community offices visited had some staff members devoted to

4. A separate directive, also from 1994, introduced certain safeguards to prevent inspectors from abusing their powers.

5. The 2001 Law on Occupational Diseases Control, and the 2002 Safe Production Law. 
employment services, paid by separate budgets, while others represented different branches of government (e.g. social assistance, services to the elderly, civil affairs and police).

\section{Box 1. Territorial divisions}

China's territorial governance has five sub-national levels, of which the first four constitute the state administration, the fifth being essentially local. At the end of 2003 , the numbers of units were as follows: ${ }^{6}$

Province level: 31 units comprising 22 provinces, 5 autonomous regions and 4 big city municipalities. The provinces dominate in population terms, having on average over 50 million inhabitants per province.

Prefecture level: 333 units. Most provinces are entirely subdivided into prefecture-level cities, whose governments thus administer large areas of mostly rural character, divided into counties, as well as city districts. But 51 prefectures have a different structure.

County level: 2861 units comprising 1642 counties, 374 county-level cities and 845 districts in higher-level cities. These units, too, include both rural and urban areas.

Township level: About 44000 units including 18100 mostly rural townships, 20200 towns and 5750 street communities in cities.

Grassroots level: 680000 villages with village committees; urban neighbourhood communities (number not known). The terms "rural area" and "urban area" usually refer to this level. The potential importance of governance at grassroots level has recently been highlighted by the introduction of competitive elections of committees in many villages and neighbourhoods.

15. The reported number of office outlets for employment services was 26000 at the end of 2003, of which 18000 were run by government at various levels and the rest by other bodies. The staff numbers probably exceeded 100000 in 2004. For the social insurance administration, the total staff number in 2004 was estimated at nearly 100 000, of which around 50000 were for pension insurance and 30000 for health care insurance. The labour inspectorate was reported to have about 43000 staff members, organised in somewhat more than 3000 inspection units (also called labour security supervision organs). The arbitration committees for labour disputes numbered about 3200 at the end of 2001, with nearly 20000 full-time or part-time arbitrators. ${ }^{7}$

16. The expansion of these administrative networks is expected to continue at a rapid pace. For social insurance, in particular, information provided by the MOLSS suggests that the staff numbers may double over the next five years. This will raise difficult questions about staff qualifications, training and auditing because it requires an increasing use of dedicated offices and specialised staff at local level. Many new offices will be needed in street communities and towns, and, as an even greater challenge, in rural townships.

6. China Labour Statistical Yearbook, 2004, Table 1-1. The figures exclude Hong Kong, China; Macau, China and Chinese Taipei.

7. The government does not publish precise data about staff resources in these office networks. The cited approximate figures were obtained from MOLSS officials and white papers (Information Office of the State Council, 2002 and 2004a). 


\section{Merging urban and rural labour markets: a desirable but distant goal}

17. Given that the Labour Law applies to all employers and employees (Section 2 of the law), the present limitation to urban labour markets of such key functions as employment services and social insurance is hardly compatible with the law. In any case, the law puts pressure on the government to extend these institutions as far as possible. In the meantime, there is some legal room for different treatment of various labour market groups, e.g. Section 71 stipulates that the level of social insurance "shall be in proportion to the level of social and economic development and social affordability."8

18. The 2002 Party Congress and the 2004 National People's Congress endorsed a series of reforms to facilitate economic activity in rural areas, including the phasing out of several rural taxes and regulatory controls. ${ }^{9}$ A similar shift of emphasis can be observed in labour market and social policy in the past two years, as gradually more attention is being paid to rural poverty and rural workers' labour market conditions. Furthermore, as discussed below, the role of China's household registration (hukou) system as a basis for different treatment of urban and rural workers has been much reduced.

19. To some extent, these policy changes in favour of rural workers must be understood against the background of the recent substantial downsizing of state-owned enterprises in urban areas, culminating in 1998 when the government issued its "two guarantees": subsistence income for the laid-off and old-age pensions. As OECD (2002) observed, the urgency of these urban problems made it inopportune in the eyes of many, at least for a while, to exacerbate competition for urban jobs by changing too rapidly the existing institutions that gave urban workers a privileged position. From now on, however, the expected incidence of further lay-offs in the urban formal sector is moderate. Indeed, statistics show that China's urban formal enterprises in general have low labour turnover by OECD standards (OECD, 2002, p. 550; China Labour Statistical Yearbook, 2003), while the opposite undoubtedly holds for informal and rural workers, although statistics are not available for them. At the same time, the gap between urban and rural wages has widened. ${ }^{10}$

20. During the OECD mission to China in March 2004, officials in all localities visited expressed a commitment to the goal of "merging urban and rural labour markets". Priority groups generally included rural migrants and poor people in rural areas as well as the urban unemployed and the laid-off. There was also a widespread recognition of the principle of equal treatment and of the need to make the labour market more efficient by removing institutional distortions. The specific problems of urban labour markets were still important, but the situation of rural workers had emerged as another policy challenge, raising questions of public governance in many policy areas. Three different but related problems can be distinguished in this context:

- The precarious situation of rural migrants in urban areas. The hukou system combined with other adverse factors, notably poor education, has for a long time prevented low-skilled migrants from

8. The OECD (2002, p. 561) has also recommended some differentiation of social insurance in order to make it affordable for various groups. See below.

9. The minister in charge of the National Development and Reform Commission said that the government aimed to increase the rural net per-capita income by 5\% in 2004 by following the principle of "giving more, taking less and loosening control” (speech by Mr. Ma Kai, second session of the National People’s Congress, March 2004).

10. The ratio of average wages in the urban formal sector compared with township and village enterprises has increased from about 1.5 in 1999 to nearly 2, reversing a previous trend of convergence (OECD, 2002, Chapter 16; China Statistical Yearbook and TVE Statistical Yearbook, various editions). The ratio of urban to rural per-capita incomes is even greater, rising from 2.6 in 1999 to 3.5 in 2002. 
becoming fully integrated into urban labour markets, leading to a pattern of excessive mobility between mostly unattractive jobs.

- Different public institutions in rural and urban areas. Some difference may be justified or inevitable due to economic conditions, but institutions should not exacerbate inequality or distort competition.

- Obstacles to labour mobility. It is difficult to determine to what extent the hukou system has reduced rural-urban migration - but it clearly has diverted large parts of it towards a limited segment of urban job markets. It can also make it difficult for urban workers to move from smaller to bigger cities. The resulting loss of economic opportunity affects most workers, but especially the rural poor.

21. Several on-going reforms focus on the first problem, amounting to a major effort to reduce discrimination against rural migrants in urban areas, and to provide them and their families with better public services, as noted below. On the other hand, no systematic extension of the present urban employment institutions to rural areas has been envisaged at national level, although this is being done to some extent in advanced regions. More limited steps in this direction are frequently mentioned, such as the extension of social insurance to workers in state farms or the provision of urban hukou status to farmers whose land is affected by urban expansion. Regarding office networks, it must be kept in mind that the territories served by offices in cities and their subdivisions frequently include rural areas (see Box 1). Nevertheless, in discussions with the OECD mission team MOLSS officials underlined that the lack of an appropriate rural office network remains a key obstacle to any extension of social insurance to rural areas.

22. The third problem - mobility barriers - is closely related to the hukou system and its reform (Box 2). This system is administered mainly by public bodies other than Labour Bureaus, which are the focus of this paper. As explained in Box 2, several reforms have reduced the importance of an individual's hukou status, while other reforms have made it easier to change hukou. Small and medium-sized cities generally give urban hukou to persons who have been living and working there for a year. But most big cities are more restrictive, with the result that $20 \%$ or more of their actual population are still subject to discriminatory treatment in several areas of public service, notably education.

23. Labour bureaus played a role in enforcing migration controls until 2003, when they were relieved of the duty to check that newly recruited workers in urban enterprises had the appropriate hukou status for the job category, as regulated by each city (see Box 2). ${ }^{11}$ This reform was certainly welcome to many officials as it removed a cumbersome control function with little relation to the other objectives of labour market policy. ${ }^{12}$ During the OECD mission in March 2004, labour bureau officials underlined that they did not check the hukou status of individuals, neither on recruitment nor in other situations, as for example when they selected participants in various programmes. (As noted below, other regulations still require labour bureaus in sending and receiving localities to organise migration, and employers who recruit migrants are expected to use these services. But individuals can also move and seek jobs for themselves.)

11. In practice, cities allowed recruitment of outsiders only for two very different types of work: high-skilled jobs for which there was a shortage of qualified applicants, and low-skilled and unattractive jobs that urban workers did not want (OECD, 2002, p. 552).

12. OECD (2002, Chapter 16, p. 568) observed that these hukou controls on recruitment had become increasingly ineffective. A competitive business climate combined with new forms of enterprise governance made it more and more difficult for the authorities to influence enterprises' choices of workers. 


\section{Box 2. The household registration (hukou) system and its reform}

\section{Main features}

Chinese citizens must carry a household register card, called hukou, issued in the locality of residence. There are two main categories:

- $\quad$ Agricultural (rural) hukou, giving a right to a small piece of land and a duty to cultivate it.

- $\quad$ Non-agricultural (urban) hukou, giving a right to urban public services in the locality concerned.

Migrants can apply for temporary registration where they live. But permanent hukou changes are accorded only under specific conditions that can be difficult to fulfil, especially for low-skilled and poor persons.

In practice, over $20 \%$ of most big cities' inhabitants have rural hukou, and so do not enjoy full rights to public services. For example, their children's education often takes place in special schools that are less attractive than other schools in urban areas.

\section{Important reform steps have been taken}

- $\quad$ Regional pilot experiments began in the 1990s and encompass several provinces since 2001, principally the eastern coastal area but also Sichuan and Anhui. In these provinces, rural citizens can obtain hukou in a city if they have permanent work and residence there. Some localities are particularly liberal, while others, including most big cities, are partly exempted.

- $\quad$ From October 2001, all towns and cities with up to about 100000 inhabitants give urban hukou to residents with fixed jobs and homes (State Council Circular No. 6).

- In January 2003, the State Council's Notice on the management of and services for rural people coming to work in cities gave many new instructions to public officials, including the following:

i. Abolish administrative controls (notably by labour bureaus) of enterprises hiring rural workers. Remove restrictions concerning the job categories in which rural workers can be hired. Simplify procedures. Abolish procedures and fees that have been imposed only on rural workers.

ii. Enterprises must sign labour contracts with rural workers and give them all rights stipulated by the Labour Law. On dismissal, employers should pay them a lump-sum compensation. Labour bureaus should reinforce their inspection of rural workers' labour contracts.

iii. Rural workers should have work injury insurance. If conditions permit, local governments can set up health care insurance for them. Training of rural workers should be organised. Rural workers' children should be guaranteed education at no extra fees, and poor families should be exempted from part of the fees.

- In June 2003, the State Council issued the notice Administrative measures on assistance and administration of poor urban vagrants and beggars. This replaced a previous regulation from 1982 about "arresting and evicting" the same groups, which had been considered to justify frequent identity checks by police. According to the new regulation, beggars and other poor rural citizens in cities should no longer be arrested and evicted, but advised to visit help centres. These centres, to be set up by city authorities other than the police, should provide food, accommodation and assistance, including tickets home or to find jobs 
24. The envisaged "merger" between urban and rural labour markets is evidently at an early stage, and its completion is a distant goal. The obstacles are largely economic, as illustrated by the gap between urban and rural wages, which has tended to widen. In 2001, the average wage in rural enterprises [township and village enterprises (TVE)] was only 54\% of the urban average wage, and the difference in labour costs was even greater because urban enterprises must pay social insurance contributions. Assuming that the difference in productivity is similarly great, it would hardly be possible to finance social insurance and other public programmes on a basis of completely equal treatment in the short term. It is therefore important to design the programmes so that they can respond to different needs and varying financing capacity, as the Labour Law’s Section 71 has foreseen concerning social insurance.

\section{Employment services and related programmes}

25. As noted above, most employment services and related programmes have been developed to meet the needs of the urban unemployed and the laid-off (xiagang), but labour bureaus have also for a long time been engaged in efforts to manage the flows of migrant workers. These policies differ in many ways, but recent developments have raised the prospect of a gradual integration within a general employment service framework. The following paragraphs consider the main issues from an administrative perspective.

26. In the labour market policies of urban China, as in OECD countries, a principal governance problem concerns the need to co-ordinate "passive" income transfers - where they exist - with "active" measures to promote job search. OECD reviews of the public employment service in numerous countries have pointed to the crucial role of job counselling and monitoring of individuals' job-search activity. ${ }^{13}$ Such procedures should be mandatory for unemployment insurance (UI) benefit recipients. As a general rule, UI administrations have been found to be most efficient where they involve a combination of effective controls - checking that beneficiaries seek jobs - and job-search assistance, with the possible addition of further measures such as training and wage subsidies. The job-search control function was weak or non-existent in the Chinese localities visited by the OECD in 2004, and previous studies in China have found that laid-off and unemployed workers often delayed their formal-sector job search in order to continue drawing benefits, while perhaps working informally (OECD, 2002; MOLSS, 2001).

27. The counselling and monitoring of unemployed clients is inevitably time-consuming and it requires well-trained and committed staff if it is to be effective. The services provided to other groups of job seekers and employers are typically less staff-intensive, and not necessarily free of charge. Many OECD governments therefore allocate staff resources to local job centres in proportion to registered unemployment, and especially to the numbers of UI benefit recipients. Although the problems and constraints are partly similar in urban China, the country does not seem to apply any automatic rule to link staff allocations with unemployment statistics.

28. However, China differs from developed countries in that most of its poor and under-employed citizens are not covered by UI. For most rural households, the chances of improving their living standards depend mainly on the off-farm labour market. ${ }^{14}$ In response to this, some labour bureaus have adopted the

13. OECD reviews of the public employment service in various countries were summarised in OECD (1996). More recent reviews concerned Greece, Ireland and Portugal (1998), the Baltic countries (2000) and Australia (2001a). See also Struyven and Steurs (2003) concerning the Netherlands.

14. In 2003, rural households received 54\% of their reported incomes from sources other than their own primary-sector activity; this comprised 35\% wages, $12 \%$ non-primary self-employment and $6 \%$ transfers (China Statistical Yearbook 2004, Tables 1-20). 
target of providing off-farm work for at least one member of every rural household. ${ }^{15}$ On average, approximately one person per rural household in China (with on average three adult members) already has off-farm employment - but these job opportunities are unevenly distributed. Worse, it is often difficult for rural job seekers to obtain reliable information about jobs available to them, which frequently are informal and of short duration, with the result that many travel long distances without knowing much about their job chances.

29. In sum, the employment service faces the need to serve a national labour market much bigger than the urban formal sector for which most of its resources were dimensioned. Its role in this broader labour market context is bound to be modest, but still potentially important, considering the need to improve the matching of labour supply and demand. A further reason for labour bureaus to play an intermediary role in labour migration, while respecting the individual freedom to move and seek jobs, is that they can and should use this role to promote an orderly application of labour law.

\section{The urban unemployed and the laid-off remain a priority ...}

30. At the end of 2003, there were about 8 million registered unemployed persons and around 6 million xiagang, or altogether about 14 million "priority" job seekers. ${ }^{16}$ Most of the registered unemployed are UI beneficiaries, who must have contributed for at least a year, while some are first-job seekers who can register after a waiting period although they get no benefits. Registered persons receive certificates of entitlement to preferential employment policies, giving a right to free job information, placement services and subsidised training. Similar rights apply to the xiagang. [By contrast, rural workers must pay for job information in many localities (Li, 2004).] The preferential policies also include fiscal advantages for up to three years to employers who hire such workers, or to the workers themselves if they start up a business. State-owned enterprises are frequently placed under pressure to recruit the unemployed or to set up subsidiaries to employ them, also with tax subsidies.

31. The special measures for xiagang represent a temporary programme, implemented since the mid-1990s but especially from 1998 when the State Council obliged state-owned enterprises to create re-employment service centres. Those concerned receive monthly income for up to three years, higher than UI benefits but lower than the previous wage, and social insurance. ${ }^{17}$ The programme had been abolished in seven coastal provinces by 2004, while elsewhere its phasing-out is foreseen within a few years. This contributed to an increase in registered unemployment by about 2 million since 2000, and a further rise by nearly a million is expected in 2004. However, the UI scheme still covers barely one-half of the labour force in urban areas, or a little over 100 million workers. A continued expansion in coverage is needed, not least in view of the changing structure of urban labour markets, with many job losses occurring in small as well as bigger firms.

32. To assess future staff requirements, it can be assumed that the number of the registered unemployed will increase with the number of adherents who contribute to UI. As in many OECD countries, benefit recipients must come to the labour office once a month. These appointments should

15. For example, the Labour Bureau of Fujian had recently adopted this policy target at the time of the OECD visit in 2004.

16. The reported unemployment rate was $4.3 \%$ of the urban labour force at the end of 2003. In general, however, Chinese unemployment statistics must be used with caution because the urban labour force is not well defined, and hukou reform makes it increasingly blurred.

17. A laid-off worker who does not find a job within three years can claim UI benefits afterwards, raising the maximum benefit duration to altogether five years. Experience shows that many find jobs, although the elderly and the low-educated often face difficulties. There have been indications that workers often delay their search for formal jobs and work informally in order to receive the benefits (OECD, 2002, p. 565). 
ideally involve job counselling, but in the offices visited by the OECD, they were often a mere formality. Judging from OECD experience, a systematic provision of monthly counselling sessions might require about one qualified staff member per 100 registered unemployed persons. The actual client-to-staff ratio appears moderately higher than this target, as in many OECD countries. (With approximately 100000 employment service staff members and 14 million unemployed and xiagang clients, the ratio is around 140; counting only qualified staff, it is higher.) Labour bureaus also offer numerous training courses, concerning as many as 4 million of their clients in 2004. Courses are procured from different providers including vocational schools, certified private schools, trade unions and large employers. ${ }^{18}$

33. By and large, the resources available for employment services and training appear quite impressive if compared only with the current numbers of UI and xiagang clients. Until now, the development of a decentralised and relatively well-equipped office network for these clients has been facilitated by the previous existence of administrative structures at the level of street communities and neighbourhood communities. In localities visited, street community offices could handle some administrative matters concerning the unemployed and provide local job information. But those who needed more qualified services were sent to district-level job centres. Street communities also co-operated with neighbourhood committees (the lowest level) which organised activities for the unemployed, including temporary jobs subsidised by labour bureaus. ${ }^{19}$

34. All told, the urban unemployed have access to a variety of services at local level. The more expensive programmes are generally reserved for the registered unemployed and the xiagang. But basic services such as information about vacant jobs are also provided to other groups. Previous regulations that excluded rural hukou holders from many jobs have been repealed, as mentioned above, and the impression gained during the mission was that employment service staff increasingly regard it as inappropriate to discriminate between clients according to their hukou status.

\section{... while there are many other potential clients}

35. Young urban job seekers looking for their first jobs, numbering nearly 10 million per year, often use the employment service, although most of them find jobs without registering as unemployed. ${ }^{20}$ The number of newly arrived rural workers in urban areas is also almost 10 million per year. The MOLSS expects the annual migration flows to increase, but such projections are extremely uncertain because the population groups that can be considered as potential migrants are very large. Furthermore, among previous migrants who already have urban work experience, there are probably millions of de facto jobless persons who are not registered as unemployed because they lack UI. In China as a whole, the number of rural hukou holders susceptible to losing their jobs or seeking a change in the near future can be counted in

18. This training often targets older workers (women older than 40, men older than 50), with special priority for former state-owned enterprise workers. For the young, in contrast, the main priority is regular education.

19. Such jobs often seem to concern the cleaning of parks, and the care of elderly persons. A neighbourhood committee visited in Fuzhou also functioned as a semi-commercial temporary job agency, dispatching unemployed people for work in restaurants.

20. Some special policy concern is devoted to college graduates, among whom an estimated $30 \%$ have difficulties in finding work. However, most of them are not considered as unemployed but as persons waiting for specialised jobs or further education. 
hundreds of millions, given the present low productivity in farming and the insecure employment conditions experienced by rural workers in other sectors. ${ }^{21}$

36. In the visited localities in Sichuan and Fujian, special employment services for rural migrants were organised at city or district level, often as "job fairs" where large numbers of job seekers were gathered, and employers could meet and interview them on the spot. Migrants arriving in the cities were required to attend courses about the Labour Law, given in classrooms receiving many hundreds of participants at a time. Labour bureaus also helped enterprises organise large-scale recruitment efforts. For example, an enterprise visited in Xiamen that intended to hire 50 unskilled workers received 600 rural applicants for interview from the employment service.

37. Many measures of this nature will undoubtedly be needed in the near future. Available resources give limited room for individual treatment of job seekers in the large groups not eligible for unemployment benefits. As far as possible, however, labour offices should offer at least some basic information and jobsearch assistance to those who demand it.

\section{Labour inspection}

38. The Labour Inspectorate, part of labour bureaus, consists of about 43000 officials whose task is to enforce the Labour Law (excluding occupational health and safety). A 1994 MOLSS directive regulates the appointment of labour inspectors, their decision powers and measures to ensure their qualifications and probity. They must undergo training and examination every third year.

39. Provincial governments organise the labour inspection in teams, operating at provincial and lower levels. Judging from discussions with officials in Sichuan and Fujian, the inspectorate's position as part of the labour bureaus is regarded as advantageous because it permits co-ordination with other functions. This favours a consistent promotion of written labour contracts and social insurance - a national priority - and also the professional treatment of many complaints and disputes.

40. Individual complaints are a chief preoccupation, and on average about $60 \%$ of them are resolved in favour of the workers. All complaints must be considered. By making this service relatively accessible, transparent and effective, the labour inspectorate has become a safety valve that appears particularly important in China, where other possible channels for workers' complaints, such as trade unions, are not independent of political powers or enterprise management. The inspectorate has no formal link with trade unions but it often co-operates with them on specific matters. ${ }^{22}$

41. Inspectors in the localities visited also conducted annual inspections of enterprises and routine controls of new labour contracts. However, as in most countries, it is not possible to conduct routine inspections in all enterprises, so in practice most inspections are motivated by complaints. In Sichuan, inspectors reportedly reviewed 380000 labour contracts during 2003, and urged employers to register 330000 workers for social insurance (mainly migrant workers in private industry); 288 illegal firms were closed. As a complement to such law enforcement, labour bureaus organise publicity campaigns among employers, and, as noted above, offer courses in labour law for rural migrants.

21. In 2003, 145 million employees appear to have worked without fixed hours, wages or other conditions. Only $10 \%$ of them had signed employment contracts with their employers and only $14 \%$ earned over 500 RMB (USD 60) per month (China Internet Information Centre, 2004).

22. By contrast, trade unions, employers and labour bureaus act formally together in labour dispute committees. The task of these committees is to resolve conflicts of interest, as opposed to conflicts of right under the Labour Law which are handled by the labour inspectorate. 
42. A strategic goal for the MOLSS is to improve the social insurance coverage of the labour force, and a special priority in the short term is to extend at least work-injury insurance and UI to rural migrants. Inspections in enterprises must therefore focus to a large extent on the establishment of labour contracts that give a right to social insurance, and, once this has been achieved, on checking the contribution payments and imposing penalties in cases of delay. It can then be difficult to place sufficient emphasis on other serious problems, such as excessive working time, wages below minimum and delayed wages. This makes it all the more important for the inspectorate to pay attention to individual complaints on such questions.

43. Despite their limitations, existing forms of inspection permit many interventions in matters of wages and working time. Faced with numerous disputes about wage arrears, the authorities have frequently responded by strengthening the inspection of wage payments. In Fujian, working time has been a particular preoccupation leading to additional inspections. According to officials encountered by the OECD team, most inspected firms were then found to follow the working-time rules; but the issue remains sensitive, partly as a result of international interest in the situation in foreign-owned firms in the province.

44. Chinese authorities face the need to remove possible grounds for suspicion that they tolerate poor labour standards in order to attract foreign investment. ${ }^{23}$ Foreign-owned companies in China are often subject to particular attention from the media and the general public in their home countries, concerned with the risk of "unfair" competition for jobs. Several NGOs, including foreign trade unions, also play a role in monitoring labour standards. But such attention is unevenly distributed between the foreign enterprises, so its impact on actual conditions is likely to vary. Inspectors in Fujian considered that the labour standards of some of the more well-known foreign firms were so high that it was unnecessary to inspect them.

45. Chinese trade unions are not independent in relation to political decision makers and they are often too connected with enterprise management to be effective as worker representatives. Trade unions can only be set up by the All-China Federation of Trade Unions, but where no union exists the workers may elect a Staff Assembly, requiring a two-thirds majority. ${ }^{24}$ The Labour Law contains rules about collective bargaining, foreseen at enterprise level in firms with at least 25 workers, but until recently it has seldom concerned wages.

46. Against this background, it must be noted as a positive sign that the MOLSS has expressed its intention to develop the collective bargaining system during 2004. It is questionable if such an objective can be achieved without giving workers more freedom to choose trade union representatives. But policy makers appear to recognise that a more market-oriented wage-setting system is needed for economic as well as social reasons. ${ }^{25}$ In April 2004, the government organised the China Employment Forum in co-operation with the ILO, proposing to collaborate with that body in order to develop its international co-operation concerning collective bargaining.

23. See, for example, annual reports of the United States Congressional-Executive Commission on China.

24. Judging from the experience of some foreign-owned enterprises, Staff Assemblies are allowed to operate independently but they cannot call themselves trade unions (Trade Union News from Finland, 2004; United States Congressional-Executive Commission on China, 2003, p. 25).

25. The exceptionally strong real-wage growth in state-owned enterprises - up by 68\% between 1999 and 2003, compared with $46 \%$ in private and mixed-owned enterprises - appears to strengthen the case for more market-driven wage setting (China Statistical Yearbook 2003, Table 5-21). 


\section{Social insurance administration}

47. For China's social insurance system, the past ten years have been a period of institution-building. Five contribution-based programmes with "socialised" management - no longer controlled by employers are now in place, but their implementation in practice has been gradual. After several pilot experiments, they are currently promoted nationwide according to basic regulations from the years shown in brackets:

- Maternity insurance (1994).

- Work injury insurance (1996).

- $\quad$ Pension insurance (1997).

- $\quad$ Medical insurance (1998).

- Unemployment insurance (1999).

48. Each programme is financially separate, but labour bureaus and their social insurance agencies co-ordinate the administration. Visited local outlets of these agencies covered the first four of the above five programmes, usually with separate desks for each of them. Concerning UI, administrative arrangements can differ at local level, but the employment service always has a key role in certifying unemployment. Varying practices are also found with respect to the collection of employer and employee contributions, a task carried out in some provinces by labour bureaus, elsewhere by tax authorities. ${ }^{26}$

49. Key governance issues concern fund management and decisions about contribution rates and benefit levels, which are partly decentralised. As discussed in more detail below with respect to pension insurance, these responsibilities often fall on city governments, especially at prefecture level, and sometimes on provincial governments. (See Box 1 above. The average prefecture has around 4 million inhabitants, of which one-third in urban areas.)

50. The existence of some local discretion about contribution rates and benefits may seem to suggest a high degree of decentralisation by OECD standards, although it must be seen against the background of China's size and regional diversity. National law and supervision limit the range of local variations and make them depend on objective criteria. For example, the maximum UI benefit must fall between the minimum wage and the minimum living standard (used for means-tested social assistance), and these two parameters also follow mandatory rules, taking account of local prices. The contribution rate for each branch of social insurance can vary around a national standard, recommended by the central government, from which most deviations have probably been motivated by the respective funds' financial positions.

51. A full harmonisation of contribution rates and benefits at national level does not appear to be on the policy agenda for the near future, perhaps mainly due to the financial responsibilities this would place on the central government. However, the central government encourages provincial governments to centralise the pooling of social insurance funds and to harmonise the system in each province. The central government has also authorised a differentiation of contribution rates and other conditions within each locality in order to facilitate an extension of the coverage to new groups of workers, especially rural migrants.

26. MOLSS officials encountered by the OECD mission regarded it as preferable for labour bureaus to collect contributions because this put them in a good position to control the legality of employment and wage conditions. Where tax authorities collect contributions, there is apparently a need to improve co-ordination and to provide labour bureaus with more detailed and timely information about contribution payments. 


\section{Extending the coverage to new groups of workers}

52. Social protection was previously limited to workers in state-owned enterprises, and not even all of them were covered. But since the early 1990s, it has been gradually extended to other urban formalsector employees, first in collective firms and then in many enterprises with shareholding, mixed or foreign ownership. In principle, social insurance is now compulsory for urban employees and voluntary for the self-employed. But only from about 2003 has it been a national policy to promote the enrolment of rural migrants.

53. The coverage of the total population remains low by international standards. Pension insurance, with the highest number of contributors, covered only $16 \%$ of the employed in 2003 , or $21 \%$ including civil servants, followed by unemployment insurance (14\%), medical insurance (11\%), work injury insurance (6\%) and maternity insurance (5\%) (see Table 2) ${ }^{27}$ Expressed as a percentage of employment in urban areas (including rural migrants), both pension insurance and UI had similar or slightly lower coverage in 2003 than in 1995, while only medical insurance of the three biggest programmes increased between 2000 and 2003.

54. Social insurance coverage is modest in most developing countries. ${ }^{28}$ For example, the ratio of pension insurance contributors to total employment in 2000 was only $11 \%$ in India and it is similarly low in most of Sub-Saharan Africa, but around 45\% in Mexico and Brazil and a little more than 50\% in Malaysia. A principal explanation is clearly the informal nature of employment, combined with the fact that the incomes of large groups of the population are too low for them to afford to pay contributions, while most of the existing programmes were designed for a relatively well-off part of the population. This situation appears comparable in many developing countries, although the relative size of the formal labour market is greater in for example Mexico, Brazil and Malaysia than in China or India. As an additional factor, there is no doubt that China's legacy of institutional segregation between urban and rural workers has exacerbated the problem of informal employment.

55. For several years after the reforms of the 1990s, the expected growth of social insurance enrolment was held back, and temporarily even reversed, by the downsizing of state-owned enterprises (SOEs). Thus in 1998, when SOE downsizing culminated, social insurance enrolment declined in absolute numbers even though it kept increasing as a percentage of SOE workers. The subsequent years saw moderate growth of pension and UI enrolment, led by the "formal" part of the urban private sector mostly large firms, often privatised or jointly-owned - whose adherence to pension insurance reached $60 \%$ by 2000. In smaller private business, often informal, it is probably still much lower.

56. From now on, a more rapid expansion of enrolment in China's principal social insurance schemes should be a realistic objective as the previous labour market segmentation gives way to a gradually more integrated labour market. All forms of social insurance should be promoted in the urban private sector, although, in China as elsewhere, it may prove impossible to collect contributions from all the selfemployed. But the government's decision in 2003 to promote the extension of social insurance to rural migrants represents a more strategic policy shift. It will probably lead to a significant expansion of enrolment already in 2004, especially for medical insurance, work-injury insurance and UI.

27. The cited enrolment data for work injury and maternity insurance were quoted from the Information Office of the State Council (2004). A voluntary pension saving scheme for rural workers had about 60 million contributors in 2003 according to the same source, but it is unclear to what extent it involves significant saving.

28. See OECD (2002), Table 16.8; concerning Brazil, see OECD, 2001b, p. 97ff. 


\section{Issues concerning the pension system}

57. While most OECD countries seek to implement uniform public pension systems, China's size and its economic and social disparity impose flexibility. Some basic parameters have been harmonised across the country, but benefits vary because first-tier pensions depend on the average wage in each locality (see Box 3). Contribution rates are generally high in old industrial regions where there are many retired SOE workers (especially the Northeast) and low in regions that until recently were less urbanised (for example, Fujian).

\section{Box 3. The public pension system}

\section{Urban workers}

Three pension tiers, of which the first two are mandatory for employees in all enterprises, but voluntary for the self-employed. Transitional rules for those who contributed before 1997.

\section{First tier: A pay-as-you-go defined-benefit programme}

Financing: Employer contributions vary around a national standard of 20\%, of which 17 percentage points for the first tier. Pooling mostly at prefecture (city) level, sometimes by province or by county.

Benefits: After at least 15 years of work, the benefit is $20 \%$ of the local average wage. The pension age is 60 (men) and 50 (most women). No first-tier benefits with under 10 contribution years.

\section{Second tier: A defined-contribution programme with individual saving accounts}

Financing: Employee contributions, now usually $7 \%$ of the wage, to be raised to $8 \%$. In addition, 3 percentage points of the employer contribution go to the individual accounts.

Administration: The government can either invest the money, mostly in bank accounts and bonds, or use it on a pay-as-you-go basis. In the latter case, which is most common, the government pays a certain rate of interest to the notional accounts.

Benefits per month: $1 / 120$ of the fund as accumulated on retirement. Thus, the programme assumes an average life expectancy of 10 years on retirement, but pensions are paid until death.

Workers who stop contributing after less than ten years in a locality (pooling unit) can withdraw the individual accounts. But they receive no first-tier pensions.

\section{Third tier: Voluntary pension saving}

Mostly enterprise pensions for employees.

\section{Rural workers}

Entirely voluntary saving, possibly with some support from communities.

Benefits according to the accumulation on individual accounts.

58. The recent transfer of the pension administration from enterprises to the State has been broadly successful, with a reported "socialisation rate" of over $99 \%$ by the end of 2002. But this would apparently not have been possible without subsidies. Provinces are in theory required to subsidise pension funds in cities that are in deficit, but in practice the central government - which gave former SOE workers the above-mentioned "two guarantees", one of which is pensions - has found it necessary to cover most of these subsidies (130 billion RMB in 2003, with 10\% matching funds from the provinces). 
59. With the present limited resources available for subsidies or transfers via the central government, no rapid harmonisation between provinces appears to be on the policy agenda. But a pooling of pension funds at province level, favoured by the MOLSS where possible, can reduce the need for centralgovernment subsidies insofar as some cities in each province report a surplus on their funds. Seven provinces currently apply such pooling, which permits a harmonisation of contribution rates and benefits at province level. This should also facilitate intra-provincial mobility.

60. Another technical question concerning the pension system's governance concerns its second tier, consisting of individual accounts. It was designed as a funded programme, a model the MOLSS now aims to introduce gradually; but its current application is limited and mainly concerns north-eastern China, where the ministry supports it as an experiment. As in other countries with similar systems, it requires the fund administrations to resolve many institutional problems, an effort that according to its proponents can be useful for the development of capital markets in the long term. However, most local governments now run the second pension tier as a notional defined-contribution scheme. In other words, they keep individual records and promise to pay out the notional funds as pensions, but instead of saving contribution revenues they spend them on a pay-as-you-go basis, just as under the first tier. The acceptability of this approach in the long run would seem to depend, in large part, on the extent to which the general public is confident that local governments will honour their pension debts. ${ }^{29}$

61. To facilitate the coverage of new participant groups, especially rural migrants, the government has authorised the use of differentiated contribution rates (Box 4). This most often involves a rebate on the employer's contribution rate to the first pension tier. But in addition, as in Chengdu, rural workers may be offered a choice between alternative insurance packages, with a variation in benefits as well as in contribution rates.

62. To the extent that a lower contribution rate can persuade more workers and employers to join the system, it can be financially advantageous to the pension fund, even if the workers concerned receive full pension rights (which is sometimes the case, but not always; see Box 4 and further below). Under realistic assumptions, the first-tier pension system's contribution rate (national standard: 17\%) is substantially higher than needed to finance the future first-tier pensions of young workers now entering the system (OECD 2002, p. 561). This rate appears to have been chosen in order to support the relatively generous pensions now paid to retired SOE workers, which follow transitional rules. A further circumstance that can be considered to motivate a lower contribution rate for rural workers, at least in the near future, is that few of the current elderly members of rural households receive any pensions.

63. Some flexibility in contribution rates and other conditions will probably be needed for many years to come. However, this does not exclude that harmonisation may be desirable as a long-term goal. In principle, a uniform system can be justified both on grounds of equity and solidarity and to facilitate labour mobility. But to fulfil the latter objective, pension rights should above all be portable, not only between employers - which is essentially the case already - but between localities and provinces, requiring more administrative co-ordination.

29. If the second tier continues to be managed on a pay-as-you-go basis, the chances that local governments will be able to pay the promised pensions can probably be enhanced for a considerable time by an upward trend in the number of contributors. But from about 2030 onwards, population ageing is set to put the payas-you-go system under increasing pressure. 
DELSA/ELSA/WD/SEM(2005)9

\section{Box 4. Social insurance on special conditions for rural migrants: two examples}

Chengdu, Sichuan introduced an optional low-cost insurance package for migrants in March 2003, covering secondtier pension insurance, work injury insurance and basic medical insurance (hospitalisation).

Flexible contributions calculated on a "base wage", defined as the previous year's average wage in the city times one of the following multiples: $60 \%, 70 \%, 80 \%, 90 \%, 100 \%, 120 \%, 150 \%$. The employer chooses a multiple for each worker, with effects on benefits as well as on contributions.

The contribution rate, applicable to the chosen "base wage", is $14.5 \%$ for the employer and $5.5 \%$ for the employee. For the self-employed, it is $20 \%$.

At the end of 2003 , this scheme covered 84000 workers, or $10 \%$ of the rural migrants in Chengdu.

Note: For urban workers in Chengdu, the standard contribution rates for pension, work injury and medical insurance are, respectively, $20 \%, 0.6$ to $2 \%$ and $7.5 \%$ for employers and $8 \%, 0 \%$ and $2 \%$ for workers. In other words, rural migrants and their employers contribute at about half of the rates that apply to urban workers.

Chengdu also gives employers in the urban private sector a 3 percentage-point rebate on their pension contributions, down to $17 \%$. This affects the city's revenues to the pay-as-you-go first tier, not the individual accounts. Such workers get the full insurance package despite the rebate.

Xiamen, Fujian offers reduced contributions to rural migrants and their employers in the standard social insurance. Contributions are then calculated on the basis of the city's minimum wage, and employers are offered an 8 percentage point rebate on the pension contribution rate, down to $6 \%$ compared with Xiamen's standard rate of $14 \%$. The employee contribution rate (for second-tier pensions) is the same as for urban workers: $8 \%$.

The rebate only affects the city's revenues in the first-tier pay-as-you-go pension scheme.

64. The present pension system also has other features that make it unsuitable for workers who move frequently. Someone who leaves a job after less than ten years and then stops contributing to the pension insurance in the city (sometimes, the province) will lose the first-tier pension rights, while any second-tier pension savings are then paid out as a lump sum. This may have limited importance for urban workers, given their traditionally low mobility. But rural migrants stay on average only three to five years in jobs, and a significant group move every year. According to labour bureau officials encountered by the OECD mission, migrants often want the lump-sum payments, and this may even contribute to their excessive mobility. Where this is the case, the programme cannot be said to fulfil the objectives of a pension system.

65. In sum, the emergence of a more integrated labour market will require further adjustments in the pension programme. Pension conditions need not be identical for all workers, but they should be transparent and individual entitlements should be portable. The present mobility patterns justify abolishing the ten-year minimum limit for contributions periods. Moreover, the pension administration should be equipped to take full account of all contributions made by an individual during his or her lifetime, regardless of where they were paid. A more centralised pension administration might facilitate this, but with good co-ordination it should also be possible in a decentralised system. 


\section{BIBLIOGRAPHY}

Avignon Academy (2002), Undeclared Work: Empirical Evidences and New Policy Issues at European Level, www.academyavignon.net/undwork.htm accessed 16 October 2004.

Belev, B. (ed.) (2003), The Informal Economy in the EU Accession countries: Size, Scope, Trends and Challenges in the Process of EU Enlargement, Centre for the Study of Democracy (in partnership with the World Bank and the Bertelsmann Group (www.csd.bg publications), pp. 139-174.

China Internet Information Centre, www.china.org.cn accessed 18 July 2004.

China Labour Statistical Yearbook (2004), China Statistics Press.

China Statistical Yearbook, various years, China Statistics Press.

Gonzaga, G. (2004), “Labor Turnover and Labor Legislation in Brazil”, Economía, Latin American and Caribbean Economic Association (LACEA), Rio de Janeiro.

Information Office of The State Council (2002), Labour and Social Security in China, white paper, http://news.xinhuanet.com/ accessed 28 October 2004.

Information Office of The State Council (2004a), China's Employment Situation and Policies, white paper, http://news.xinhuanet.com/ accessed 28 October 2004.

Information Office of The State Council (2004b), China's Social Security and its Policy, white paper, http://english.people.com.cn/200409/07/eng20040907_156193.html accessed 4 November 2004.

Li, Bingqin (2004), Urban Social Exclusion in Transitional China, Case Paper No. 82, London School of Economics, London.

McKinsey\&Company (2004), Eliminando as Berreiras ao Crescimento Econômico e à Economia Formal no Brasil, São Paulo.

MOLSS (Ministry of Labour and Social Security) (2001), Issues on Perfecting Social Security System and Re-employment of Laid-off Workers, Beijing.

OECD (1996), The OECD Jobs Strategy: Enhancing the Effectiveness of Active Labour Market Policies, OECD, Paris.

OECD (1998), The Public Employment Service: Greece, Ireland, Portugal, OECD, Paris.

OECD (2001a), Innovations in Labour Market Policies: The Australian Way, OECD, Paris.

OECD (2002), China in the World Economy: The Domestic Policy Challenges, OECD, Paris. 
OECD (2004), Employment Outlook, OECD, Paris.

OECD (2005a), Governance in China, OECD, Paris.

OECD (2005b), Economic Surveys: Brazil, OECD, Paris.

Struyven, L., and G. Steurs (2003), The Competitive Market for Employment Services in the Netherlands, OECD Social, Employment and Migration Working Paper No. 13, OECD, Paris.

Trade Union News from Finland (2004), "Clothing Chain H\&M Seeks Progress in China”, http://www.artto.kaapeli.fi/unions/T2004/h07 accessed 4 November 2004 (also in Asian Labour News, 17 March 2004, http://www.asianlabour.org/archives/001226.php).

United States Congressional-Executive Commission on China (2003), Annual Report, Washington DC

Winkler, R. 1997, “The Size and Some Effects of the Underground Economy in Mexico”, in O. Lippert and M. Walker (eds.), The Underground Economy: Global Evidence of its Size and Impact, The Fraser Institute, http://collection.nlc-bnc.ca/100/200/300/fraser/underground/index.html accessed 16 October 2004. 
Table 1. Employed persons by main labour market segment

Market segment
Estimated percentage distribution at the end of 2003

Urban formal employees* 15

Of which: Government, state-owned enterprises and urban collectives 11 Shareholding, jointly-owned enterprises etc. and foreign-owned firms

Self-employment and employees in small private firms, registered in urban areas 7

Other employment in urban areas** 13

Off-farm jobs in rural areas 17

Of which: Small private firms and self-employment

Agriculture (mostly self-employment)

49

Total 100

Total, persons (in millions)

*Reported "staff and workers" (14 percentage points) and a few others

${ }^{* \star A}$ Approximate estimate, including many rural migrants.

Source: China Statistical Yearbook 2004, various tables. 
Table 2. Workers enrolled in social insurance

Millions and percentage of employment

\begin{tabular}{|c|c|c|c|c|c|c|c|c|c|c|}
\hline & \multicolumn{4}{|c|}{ Pension insurance* } & \multicolumn{3}{|c|}{ Unemployment insurance } & \multicolumn{3}{|c|}{ Medical insurance } \\
\hline & $\begin{array}{c}\text { Million } \\
\text { contributors }\end{array}$ & $\begin{array}{l}\text { Percent of } \\
\text { total } \\
\text { employment }\end{array}$ & $\begin{array}{l}\text { Percent of } \\
\text { employment } \\
\text { in urban } \\
\text { areas }\end{array}$ & $\begin{array}{l}\text { Percent of } \\
\text { employment } \\
\text { in SOEs }\end{array}$ & $\begin{array}{c}\text { Million } \\
\text { contributors }\end{array}$ & $\begin{array}{l}\text { Percent of } \\
\text { total } \\
\text { employment }\end{array}$ & $\begin{array}{l}\text { Percent of } \\
\text { employment } \\
\text { in urban } \\
\text { areas }\end{array}$ & $\begin{array}{c}\text { Million } \\
\text { contributors }\end{array}$ & $\begin{array}{l}\text { Percent of } \\
\text { total } \\
\text { employment }\end{array}$ & $\begin{array}{c}\text { Percent of } \\
\text { employment } \\
\text { in urban } \\
\text { areas }\end{array}$ \\
\hline 1994 & 85 & 13 & 46 & 63 & 80 & 12 & 43 & 4 & 1 & 2 \\
\hline 1995 & 87 & 13 & 46 & 63 & 82 & 12 & 43 & 7 & $\overline{1}$ & 4 \\
\hline 1996 & 88 & 13 & 44 & 63 & 83 & 12 & 42 & 8 & 1 & 4 \\
\hline 1997 & 87 & 12 & 42 & 62 & 80 & 11 & 38 & 16 & 2 & 8 \\
\hline 1998 & 85 & 12 & 39 & 73 & 79 & 11 & 37 & 15 & 2 & 7 \\
\hline 1999 & 95 & 13 & 42 & 75 & 99 & 14 & 44 & 15 & 2 & 7 \\
\hline 2000 & 104 & 14 & 45 & 80 & 104 & 14 & 45 & 29 & 4 & 12 \\
\hline 2001 & 108 & 15 & 45 & .. & 104 & 14 & 43 & 55 & 7 & 23 \\
\hline 2002 & 111 & 15 & 45 & .. & 102 & 14 & 41 & 69 & 9 & 28 \\
\hline 2003 & 116 & 16 & 45 & .. & 104 & 14 & 40 & 80 & 11 & 31 \\
\hline
\end{tabular}

*Civil servants'pension plans, not shown, covered an additional 38 million workers in 2003 (5\% of total employment, 15\% in urban areas).

Source: China Statistical Yearbook, 2-1 and 2004. 


\section{OECD SOCIAL, EMPLOYMENT AND MIGRATION WORKING PAPERS}

Most recent releases are:

No. 29 NET SOCIAL EXPENDITURE, 2005 EDITION (forthcoming) Willem Adema \& Maxime Ladaique

No. 28 WELFARE REFORM IN EUROPEAN COUNTRIES: A MICROSIMULATION ANALYSIS (2005) Herwig Immervoll, Henrik Jacobsen Kleven, Claus Thustrup Kreiner and Emmanuel Saez

No. 27 TRENDS AND DETERMINANTS OF FERTILITY RATES: THE ROLE OF POLICIES (2005) Cristina d'Addio \& Marco Mira d'Ercole

No. 26 THE “ENABLING STATE?” (2005) Neil Guilbert

No. 25 COUNTING IMMIGRANTS AND EXPATRIATES IN OECD COUNTRIES: A NEW PERSPECTIVE (2005) Jean-Christophe Dumont and Georges Lemaître

No. 24 TAXATION, ETHNIC TIES AND THE LOCATION CHOICE OF HIGHLY SKILLED IMMIGRANTS (2005)

Thomas Liebig and Alfonso Sousa-Poza

No. 23 SHOULD WE EXTEND THE ROLE OF PRIVATE SOCIAL EXPENDITURE? (2005) Mark Pearson and John P. Martin

No. 22 INCOME DISTRIBUTION AND POVERTY IN OECD COUNTRIES IN THE SECOND HALF OF THE $1990 S$ (2005)

Michael Förster and Marco Mira d'Ercole

No. 21 DESIGN CHOICES IN MARKET COMPETITION FOR EMPLOYMENT SERVICES FOR THE LONGTERM UNEMPLOYED (2004)

Ludo Struyven

No. 20 BENEFIT COVERAGE RATES AND HOUSEHOLD TYPOLOGIES: SCOPE AND LIMITATIONS OF TAX-BENEFIT INDICATORS (2004)

Herwig Immervoll, Pascal Marianna and Marco Mira D’Ercole

No. 19 AVERAGE AND MARGINAL EFFECTIVE TAX RATES FACING WORKERS IN THE EU. A MICROLEVEL ANALYSIS OF LEVELS, DISTRIBUTIONS AND DRIVING FACTORS (2004)

Herwig Immervoll

No. 18 INDICATORS OF UNEMPLOYMENT AND LOW-WAGE TRAPS (Marginal Effective Tax Rates on Employment Incomes) (2004)

Giuseppe Carone, Herwig Immervoll, Dominique Paturot and Aino Salomäki

No. 17 TAKE-UP OF WELFARE BENEFITS IN OECD COUNTRIES: A REVIEW OF THE EVIDENCE (2004) Virginia Hernanz, Franck Malherbet and Michele Pellizzari

No. 16 THE SWEDISH ACTIVITY GUARANTEE (2004)

Anders Forslund, Daniela Froberg and Linus Lindqvist

No. 15 LOW FERTILITY RATES IN OECD COUNTRIES: FACTS AND POLICY RESPONSES (2003) Joëlle Sleebos

No. 14 NATIONAL VERSUS REGIONAL FINANCING AND MANAGEMENT OF UNEMPLOYMENT AND RELATED BENEFITS: THE CASE OF CANADA (2003)

David Gray

Recent available working papers can be found on the OECD website: www.oecd.org/els/workingpapers.

Other series of working papers available from the OECD include: OECD HEALTH WORKING PAPERS 


\section{RECENT RELATED OECD PUBLICATIONS:}

BABIES AND BOSSES: Reconciling Work and Family Life, Volume 4 Canada, Finland, Sweden and the United Kingdom (2005)

PENSIONS AT A GLANCE: Public policies across OECD countries (2005)

EXTENDING OPPORTUNITIES - How active social policy can benefit us all (2005)

SOCIETY AT A GLANCE: OECD Social Indicators (2005)

OECD EMPLOYMENT OUTLOOK (2005)

AGEING AND EMPLOYMENT POLICIES: AUSTRIA (2005)

AGEING AND EMPLOYMENT POLICIES: NETHERLANDS (2005)

AGEING AND EMPLOYMENT POLICIES: AUSTRALIA (2005)

AGEING AND EMPLOYMENT POLICIES: UNITED STATES (2005)

AGEING AND EMPLOYMENT POLICIES: FRANCE (2005)

TRENDS IN INTERNATIONAL MIGRATION: SOPEMI (2004)

MIGRATION FOR EMPLOYMENT: BILATERAL AGREEMENTS AT A CROSSROADS (2004)

INCOME DISPARITIES IN CHINA: AN OECD PERSPECTIVE (2004)

BENEFITS AND WAGES: OECD Indicators (2004)

REFORMING PUBLIC PENSIONS: SHARING THE EXPERIENCES OF TRANSITION AND OECD COUNTRIES (2004)

ASSET BUILDING AND THE ESCAPE FROM POVERTY: A NEW WELFARE POLICY DEBATE (2003)

MANAGING DECENTRALISATION: A NEW ROLE FOR LABOUR MARKET POLICY (2003)

COMBATING CHILD LABOUR: A REVIEW OF POLICIES (2003)

BABIES AND BOSSES: Reconciling Work and Family Life, Volume 2, Austria, Ireland and Japan (2003) TRANSFORMING DISABILITY INTO ABILITY: Policies to Promote Work and Income Security for Disabled People (2003)

For a full list, consult the OECD On-Line Bookstore at www.oecd.org 